\title{
Fear grows as Daesh, warlords battle for control of Afghan trade hub
}

Fazelminallah Qazizai

August 25, 2018 20:10

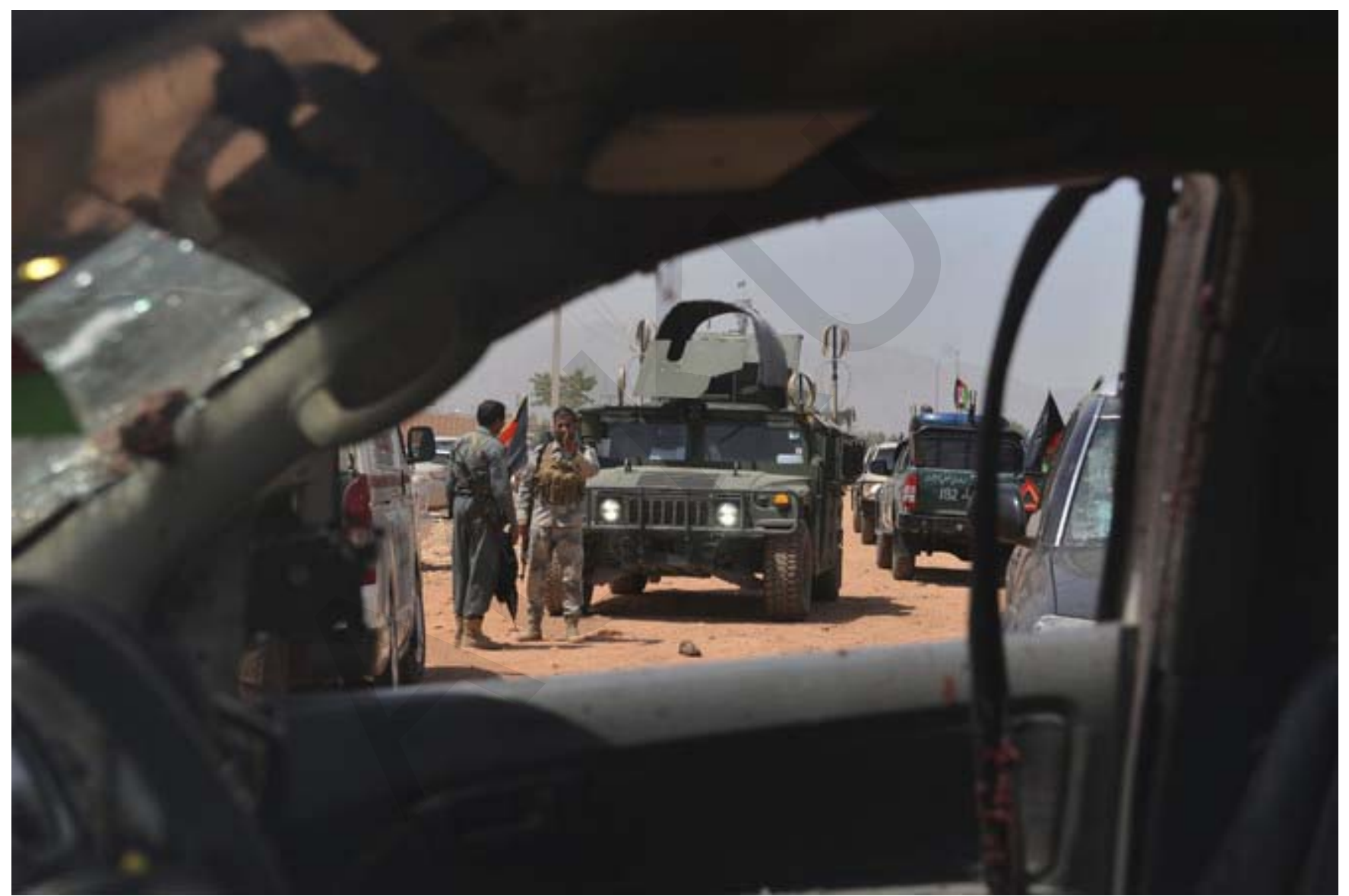

Security personnel inspect the side of a suicide attack near the office of the Election Commission in Jalalabad city, capital of eastern Nangarhar province, Afghanistan, Saturday, Aug. 25, 2018. (AP) Updated 25 August 2018

Fazelminallah Qazizai

August 25, 2018 20:10

663

- Daesh expanded its operations in Afghanistan after the killing of Hakimullah Mehsud, head of Tehreek-e-Taliban Pakistan (TTP), in late 2014 
- The militant group was responsible for 52 percent of civilian casualties in Afghanistan in the first half of 2018, according to the UN

JALALABAD: The provincial capital of Jalalabad, a vital hub for cross-border trade with Pakistan, was once considered relatively safe. That reputation is now under threat as Daesh steps up its battle for political and military control of Nangarhar province.

The militant group recently turned Jalalabad into a battleground - making it one of the most dangerous places in Afghanistan — in response to recent US missile attacks aimed at Daeshcontrolled areas. The attacks have been responsible for killing civilians rather than militants, many believe.

"Dealing with the current situation is beyond the capacity of local and central governments. The president needs to talk to the Americans and ask them what the bilateral security agreement (signed in September 2014) is for," Dr. Mohammed Nasir Kamawal, a provincial councilor, told Arab News.

Daesh expanded its operations in Afghanistan after the killing of Hakimullah Mehsud, leader of Tehreek-e-Taliban Pakistan (TTP), in late 2014. Many in the TTP refused to recognize his successor, Mullah Fazlullah, as leader of the umbrella organization.

In early 2015, tensions in Achin, a district in the south of Nangarhar, escalated after the Taliban tried to prevent a spate of kidnappings by militants allied with Daesh in the neighboring district of Bati Kot. This resulted in violent clashes between the two groups, and some of the Taliban in Achin decided to switch sides in the wake of the conflict. Achin eventually fell to Daesh later that year.

On Jan. 26, 2015, a spokesman for Daesh, Abu Muhammad Al-Adnani, released an audio statement in which he accepted the earlier pledge of allegiance from Taliban fighters and announced the expansion of Daesh's "caliphate" with the creation of "Khurasan Province." Hafiz Khan Saeed was appointed as local governor and Daesh began recruiting Taliban defectors. In July 2018, the UN reported that the number of civilians killed in Afghanistan had reached record levels in the first half of the year, up by 1 percent on the same period in 2017. It claimed that Daesh was responsible for 52 percent of the casualties.

"The situation is bleak," said Khalid Khan, 38, a Jalalabad resident. "Schools and universities are closed and even the hospital is empty. Only desperate and urgent cases are being treated. The city wears a deserted look."

While Daesh competes for territory with the Taliban in various districts and attempts a show of power inside the city, Jalalabad has become a fiefdom of several mafia-like families.

"There are two reasons security has become bad. One is Daesh, the other the warlords and strongmen who deal with government and act out of law," said Obidullah Mujahid, a local businessman.

The warlords who built their reputations in the anti-Soviet resistance of the 1980s include Speaker of the Senate Fazel Hadi Muslimyar, and Members of Parliament Hajji Zahir Qadir and Hazrat Ali.

"Fighting Daesh alone is not enough," said Gen. Amrullah Aman, a former army general and military expert.

"The government also needs to struggle with local warlords who grab people's land and deprive them of their rights. People are looking to an alternative (Daesh) to take revenge," he said. 